\title{
Implikasi Lingkungan Keluarga Terhadap Pembentukan Kepribadian Siswa SDN 4 Gunung Rajak
}

\author{
Ahmad Izzuddin \\ STIT Palapa Nusantara \\ Email: izzuddinbn@yahoo.co.id
}

\begin{abstract}
Abstrak: Lingkungan keluarga merupakan dasar pertama dan utama dalam pembentukan kepribadian. Peran orang tua dalam mendidik anak cenderung menggunakan kekerasan baik secara fisik maupun fsikis akan sangat berimplikasi pada kondisi kejiwannya. Anak yang dididik dengan menggunakan kekerasan akan cenderung menerapkan pola prilaku yang mereka terima dalam kesehariaanya baik dilingkungan keluarga maupun lingkungan pendidikan lainnya. Penelitian ini menggunakan pendekatan kualitatif naturalistik dengan jenis penelitian Kualitatif. Metode pengumpulan data menggunakan metode observasi, wawancara dan dokumentasi. Dalam penelitian ini dijelaskan bahwa lingkungan keluarga merupakan lingkungan pendidikan pertama yang sangat penting dalam membentuk pola kepribadian anak. Karena di dalam keluarga, anak pertama kali mendapat pengetahuan tentang nilai dan norma. Konsepsi Islam tentang lingkungan keluarga sangat positif. Lingkungan yang indah, harmonis, sehat, nyaman dan tentram akan mempengaruhi perasaan dan jiwa anak didik yang dapat membentuk kepribadian mereka menjadi pribadi yang sopan dan patuh terhadap orang tua.
\end{abstract}

Kata kunci: Lingkungan Keluarga, Pembentukan Kepribadian Siswa.

\section{Pendahuluan}

Islam sebagai agama memiliki makna yang cukup luas, merupakan petunjuk bagi jalan hidup manusia dan merupakan rahmat bagi seluruh alam. Selain itu, Islam merupakan pandangan hidup sekaligus sebagai tujuan hidup manusia. Islam sebagai agama wahyu terakhir memiliki kebenaran yang bersifat universal dan absolut, artinya tidak bertentangan dengan kebenaran akal meskipun kebenaran akal tersebut bersifat relatif.

Dalam pandangan Islam, anak merupakan amanat yang dibebankan oleh Allah Swt. Kepada orang tuanya. Karena itu orang tua harus menjaga dan memelihara 
serta menyampaikan amanat itu kepada yang berhak menerimanya. Karena manusia adalah milik Allah Swt. Mereka harus mengantarkan anaknya untuk mengenal dan menghadapkan diri kepada Allah Swt selaku khaliknya. Pernyataan tersebut diperjelas dalam Al-Qur'an Surat At-Tahrim ayat 6, Allah SWT berfirman yang artinya:

"Hai orang-orang yang beriman, peliharalah dirimu dan keluargamu dari api neraka yang bahan bakarnya adalah manusia dan batu. Penjaganya Malaikat yang kasar, keras, dan tidak mendurhakai Allah terhadap apa yang diperintahkan".(DEPAG RI, ALQuran dan Terjemahannya 1978:560)

Dalam Islam, keluarga dikenal dengan istilah usrah, nasl, 'ali, dan nasb Abdul Mujib (2008 : 226). Keluarga merupakan institusi pertama tempat anak membangun karakternya. Orang tua hendaknya menerapkan pola asuh dan pendidikan yang sehat dan baik dalam keluarga. Sehingga kepribadiannya akan menjadi pribadi yang menyebarkan karakter positif pada lingkungan dan bukan sebaliknya. Bagi anak, keluarga merupakan persekutuan hidup pada lingkungan keluarga tempat di mana ia menjadi pribadi atau diri sendiri. (Hasbullah, 2008 : 9).

Bertolak dari uraian di atas, Zakiah Darajat mengatakan bahwa: akibat yang mungkin terjadi pada anak-anak apabila ia kurang diperhatikan itu banyak sekali, antara lain akan terganggu kesehatan mentalnya. Di antara kelakuan yang dapat terlihat dengan nyata ialah :

a) Suka memperhatikan gerak gerik orang tua, banyak tanya seperti pergi kemana, dan mana kadang-kadang menyakitkan orang tua

b) Sering melakukan hal-hal yang menarik perhatian untuk memperoleh kasih sayang

c) Kelakuan dan sikap menunjukan bahwa ia benci pada orang, acuh tak acuh dsb. (Zakiah Darajat, 1988: 80).

Zuhairini dkk ( 2008 : 177) menjelaskan bahwa :

"Lingkungan keluarga adalah lingkungan pendidikan yang pertama, karena dalam keluarga inilah anak pertama mendapatkan pendidikan dan bimbingan dari orang tuanya atau anggota keluarganya. Di dalam keluarga inilah tempat meletakkan dasardasar kepribadian anak didik pada usia yang masih muda, karena pada usia ini anak akan lebih peka terhadap pengaruh dari pendidikannya (orang tua dan anggota yang lainnya)". 
Berlandaskan pada dalil naqli dan beberapa teori tersebut dapat disimpulkan bahwa Peran keluarga merupakan dasar pertama dan utama dalam pembentukan kepribadian anak. Jika melihat peran orang tua yang dalam mendidik anak-nya cenderung menggunakan kekerasan baik secara fisik maupun fsikis akan sangat berimplikasi pada kondisi kejiwannya, baik dalam perkembangan mental ataupun prilaku yang dapat mencerminkan jati diri \kepribadian seorang anak di masa depan.

Anak yang dididik dengan menggunakan kekerasan (perlakuan kasar orang tuanya) akan cenderung menerapkan pola prilaku yang mereka terima dalam kesehariaanya baik dilingkungan keluarga maupun lingkungan pendidikan lainnya, hal tersebut akan terlihat saat anak mulai melakukan intraksi dengan lingkungan diluar rumah, misalnya dilingkungan madrasah, ataupun lingkungan sosial lainnya yang melibatkan orang bayak (masyarakat) begitu juga dengan orang tua yang terbiasa menerapkan gaya hidup mewah pada anaknya hal tersebut akan sangat mempengaruhi kepribadian setiap anak di masa depan.

Sebaliknya, orang tua yang selalu memberikan kasih sayang yang tulus serta membekali anak mereka dengan pengetahuan tentang agama sejak dini dan menerapkan pola hidup yang sederhana akan melahirkan pribadi berkarakter positif yang didambakan setiap orang tua. Oleh karena itu, baik buruknya kepribadian seorang anak tergantung pada orang tua dan lingkungannya. Perlu ditekankan bahwa lingkungan keluarga tidak seratus persen mempengaruhi manusia, karena Allah menciptakan manusia disertai dengan adanya ikhtiar dan hak pilih. Dengan ikhtiarnya, manusia bisa mengubah nasibnya sendiri.

\section{METODE}

\section{Pendekatan Penelitian}

(Sugiyono, 2011:15), Menjelaskan bahwa :

"metode penelitian kualitatif adalah metode penelitian yang berlandaskan pada filsafat postpositivisme, digunakan untuk meneliti pada kondisi obyek yang alamiah, (sebagai lawannya eksperimen) dimana peneliti adalah sebagai instrument kunci, pengambilan sampel sumber data dilakukan secara purposive dan snowbaal, teknik pengumpulan dengan trianggulasi (gabungan), analisis data bersifat induktif/kualitaif, dan hasil penelitian kualitatif lebih menekankan makna dari pada generalisasi”. 
Penelitian ini menggunakan pendekatan kualitatif-Naturalistik dengan jenis penelitian Kualitatif. Merupakan penelitian yang dipakai untuk memperoleh informasi mengenai Bagaimanakah Implikasi Lingkungan Keluarga Terhadap Pembentukan Kepribadian Anak Pada Siswa Kelas IV SDN 4 Gunung Rajak di Kecamatan Sakra Barat. Alasan penulis menggunakan metode kualitatif karena, Ia bermaksud memahami situasi sosial secara mendalam, menemukan pola, hipotesis dan teori.

Dalam penelitian kualitatif, karena permasalahan yang dibawa oleh peneliti masih bersifat sementara, maka teori yang digunakan dalam penyusunan proposal penelitian kualitatif juga masih bersifat sementara dan akan berkembang setelah peneliti memasuki lapangan atau konteks sosial. Terkait dengan teori, dalam penelitian kualitatif bersifat menemukan teori.

\section{Prosedur Pengumpulan Data}

Menyusun instrumen adalah pekerjaan penting dalam penelitian, akan tetapi mengumpulkan data jauh lebih penting, maka menyusun instrumen harus ditangani dengan serius agar data yang diperoleh sesuai dengan data yang diinginkan. Kegiatan penelitian ini pada dasarnya meliputi empat pokok, yaitu: (1) tahap pra lapangan, (2) pekerjaan lapangan, (3) Analisis data, (4) penulisan laporan.

Tahap pra lapangan yaitu peneliti mempersiapkan diri sebelum mendatangi tempat penelitian. Adapun persiapan yang dilakukan peneliti, yaitu menyusun proposal penelitian, mengurus surat izin penelitian, menyiapkan pertanyan-pertanyaan untuk dilontarkan di tempat penelitian, dan pedoman pengumpulan data.

Tahap pekerjaan lapangan, peneliti mengumpulkan data di lokasi penelitian dengan survey, observasi, interview (wawancara), dokumentasi, mengkaji data yang terkumpul, menguji keabsahan data dan memfokuskan data untuk persiapan analisis awal, Untuk lebih jelasnya, berikut penulis uraikan masing-masing metode diantaranya adalah :

1. Metode Observasi

Metode observasi adalah pengumpulan data dan pencatatan dengan sistematis fenomena-fenomena yang diselidiki. (Sutrisno Hadi, 1984: 136). 
Dalam kenyataannya penggunaan metode observasi dalam pengumpulan data dapat dibagi dalam dua teknik yaitu :

a. Teknik observasi secara langsung

Yakni teknik pengumpulan data dimana penyelidik mengadakan pengamatan secara langsung (tanpa alat) terhadap gejala subyek yang diselidiki

b. Teknik observasi tidak langsung

Maksudnya adalah teknik pengumpulan data dimana peneliti mengadakan pengamatan terhadap gejala-gejala subyek yang diselidiki diperantarai sebuah alat.

2. Metode interview

Interview artinya melakukan wawancara langsung secara lisan antara interviweer dengan responden, metode interview ini cukup praktis dari segi penggunaanya dan gampang dalam pelaksanaanya. Adapun interview yang dimaksud di sini adalah seperti yang diungkapkan Sutrisno Hadi bahwa"interview dapat dipandang sebagai alat pengumpulan data dengan jalan tanya jawab sepihak yang dilaksanakan secara sistematis kepada tujuan penelitian atau penyelidikan".

Adapun cara penulisan dalam mempergunakan metode interview ini adalah :

pertama penulis mengadakan pengenalan diri pada dewan guru dan staf Kecamatan Keruak dengan maksud memohon izin untuk mengadakan penelitian. Di samping itu, penulis perlu menyampaikan tujuan penelitian agar tidak terjadi salah pengertian dalam penelitian yang dilaksanakan, sehingga diharapkan nantinya sumber data dapat memberikan informasi sesuai dengan data yang diharapkan.

Kedua Saat interview berlangsung, penulis mengadakan pencatatan-pencataan hasil interview yang diperoleh sebagai data. Hal ini dilaksanakan agar data yang diperoleh tidak terlupakan sekaligus untuk memudahkan penulis mengklasifikasikan data yang terkumpul.

3. Metode dokumentasi 
Metode dokumentasi adalah mencari data mengenai hal-hal atau variabel yang berupa catatan, transkrip, buku, surat kabar, majalah, prasasti, notulen rapat, agenda dan sebagainya. (Arikunto, 1993 : 202).

Dibandingkan dengan metode yang lain, metode dokumentasi tidaklah begitu sulit dalam arti apabila ada kekeliruan sumber datanya masih tetap (belum berubah). Dengan metode dokumentasi ini penulis bermaksud untuk mencatat data-data yang bersumber dari dokumentasi resmi SDN 4 Gunung Rajak Kecamatan Sakra Barat Sbb:

a) Daftar guru SDN 4 Gunung Rajak Kecamatan Sakra Barat.

b) Daftar pegawai SDN 4 Gunung Rajak Kecamatan Sakra Barat.

c) Daftar kelengkapan fasilitas di SDN 4 Gunung Rajak Kecamatan Sakra Barat. 


\section{Teknik Analisis Data}

Dalam penelitian kualitatif, data diperoleh dari berbagai sumber, dengan menggunakan teknik pengumpulan data yang bermacam-macam (trianggulasi), dan dilakukan secara terus-menerus sampai datanya jenuh.(Sugiyono, 2009:426). Data yang telah terkumpul dalam penelitian ini perlu diadakan analisis yang cermat, teliti dan ulet, sehigga dapat menemukan kesimpulan yang obyektif dari penelitian yang dilakukan.

Untuk itu data yang diperoleh diolah dengan menggunakan metode deduktif dan metode induktif. Berikut penulis uraikan untuk lebih jelasnnya:

Metode Deduktif adalah : metode yang bertitik tolak dari suatu dalil atau prinsip yang normative untuk menilai suatu kejadian dari berbagai macam kasus.

Jadi peneliti menggunakan metode deduktif untuk memberikan landasan uraian dari berapa teori dan pendapat yang menggunakan buku sebagai sumber skunder agar dapat memenuhi kelengkapan data yang dibutuhkan untuk penulisan laporan penelitian yang lugas dan sesuai dengan keinginan para pembaca.

Metode Induktif adalah suatu cara menganalisa data yang berangkat dari fakta yang khusus ke umum.

Dengan menggunakan beberapa metode untuk mengumpulkan dan menganalisa data yang diperoleh dilapangan, penulis mengharapkan hasil yang terbaik dalam penulisan laporan sehingga data yang penulis peroleh dapat dipertanggung jawabkan kevaliditasan datanya.

Pada tahap analisis data, peneliti melakukan analisis data yang telah terkumpul, mengadakan pengayaan dan pendalaman data sesuai dengan tempat penelitian. Dan akhirnya membuat suatu hasil data yang berbentuk tulisan.

Landasan Teori

\section{Definisi Implikasi}

Dalam kamus ilmiah populer, implikasi adalah keterlibatan atau keadaan terlibat.

Dilihatya (dalam http://dilihatya.com/2411/pengertian-implikasimenurut-para-ahli/didownload tanggal 14 maret 2016) menjelaskan beberapa 
pendapat beberapa pendapat para ahli mengenai definisi implikasi diantaranya adalah :

Pengertian implikasi secara bahasa mempunyai makna sesuatu yang telah tersimpul atau disimpulkan didalam suatu penelitian. Implikasi berfungsi untuk membandingkan hasil penelitian yang lalu dengan hasil penelitian yang baru saja dilakukan.

Ada tiga jenis implikasi yang sering digunakan dalam keperluan penelitian diantaranya adalah :

1) ImplikasiTeoritis

Seorang peneliti menjadikan gambar secara lengkap mengenai implikasi teoritis dari sebuah penelitian dengan tujuan untuk meyakinkan penguji pada kontribusi ilmu pengetahuan maupun teori yang digunakan dalam menyelesaikan sebuah masalah penelitian.

2) Implikasi Manajerial

Peneliti menyajikan impilkasi tentang berbagai kebijakan yang mampu dihubungkan dengan berbagai macam temuan yang diperoleh dari sebuah penelitian, implikasi ini dapat memberikan suatu kontribusi yang praktis untuk manajemen.

3) Implikasi metodologi

Bersifat operasional dan mampu menyajikan refleksi penulis mengenai metodologi yang akan dipakai dalam penelitian yang telah dilakukan, sebuah penelitian mampu menyajikan pendekatan-pendekatan yang bisa dipakai dalam sebuah penelitian lanjutan dan penelitian lain dengan fungsi mempermudah atau meningkatkan mutu dari penelitian itu sendiri

Perlu dijelaskan bahwa maksud dari implikasi yang penulis kutip disini adalah apakah ada? atau adanya keterlibatan dari lingkungan keluarga terhadap pembentukan kepribadian anak.

\section{Lingkungan}

Pengertian Lingkungan 
Menurut Beni Ahmad Saebani dan Hendra Akhdiyat (2009: 262) "lingkungan adalah ruang dan waktu yang menjadi tempat eksistensi manusia".

Zakiah Darajat (1995 : 63-64) menjelaskan bahwa :

"Lingkungan mencakup iklim dan geografis, tempat tinggal adat istiadat, pengetahuan pendidikan dan alam. dengan kata lain lingkungan ialah segala sesuatu yang tampak dan terdapat dalam alam kehidupan yang senantiasa berkembang, ia adalah seluruh yang ada, baik manusia maupun benda buatan manusia atau alam yang bergerak, kejadian-kejadian atau hal-hal yang mempunyai hubungan dengan seseorang".

Oleh karena itu Lingkungan pada dasarnya memiliki pengaruh yang sangat besar terhadap penyelengaraan pendidikan, terutama pada perkembangan jiwa dan pembentukan kepribadian anak didik.

\section{Keluarga}

Pengertian Keluarga

"Keluarga adalah unit terkecil dalam masyarakat yang terdiri dari suami istri, atau suami istri dan anaknya, atau ayah dan anaknya, atau ibu dan anaknya, atau keluarga segaris lurus ke atas atau ke bawah sampai dengan derajat ketiga".(Perpustakaan Nasional RI, 2009 : 12)

F.J. Brown dalam Syamsu (2000 : 36) menjelaskan bahwa ditinjau dari sudut pandang sosiologi, keluarga dapat diartikan dua macam, yaitu a) dalam arti luas, keluarga meliputi semua pihak yang berhubungan darah atau keturunan yang dapat dibandingkan dengan "clan" atau marga; b) dalam arti sempit keluarga meliputi orang tua dan anak".

Memperhatikan pendapat tersebut dapat disimpulkan bahwa keluarga merupakan unit terkecil dari masyarakat yang terdiri dari orang tua dan anak-nya yang terikat oleh hubungan darah yang dapat dibandingkan dengan clan.

\section{Pembentukan}

Pengertian pembentukan : 
Menurut KBBI Edisi ke-tiga (2005 : 135) Pembentukan berasal dari kata "bentuk" yang artinya wujud yang ditampilkan. Sedangkan pengertian pembentukan sendiri adalah proses, cara, perbuatan membentuk.

Pendapat beberapa Ahli tentang Pembentukan :

Ibnu Qoyyim Al-Jauzi, sebagaimana dikutip oleh M. Athiyah al-Abrasy (1990 : 107) menjelaskan bahwa :

"pembentukan yang utama ialah waktu kecil, maka apabila seorang anak dibiarkan melakukan sesuatu (yang kurang baik) dan kemudian telah menjadi kebiasaannya, maka akan sukarlah meluruskannya”.

Tujuan utama dari kebiasaan ini, adalah penanaman kecakapankecakapan berbuat dan mengucapkan sesuatu agar cara-cara yang tepat dapat dikuasai oleh siterdidik yang terimplikasi mendalam bagi pembentukan selanjutnya. pembentukan lebih dititikberatkan pada perkembangan akal (pikiran, minat, dan sikap atau pendirian.).

Menurut Ahmad D. Marimba (1989 : 88) bahwa pembentukan pada taraf ini terbagi dalam tiga bagian, yaitu :

1. Formil

Pembentukan secara formil, dilaksanakan dengan latihan secara berpikir, penanaman minat yang kuat, dan sikap (pendirian) yang tepat. Tujuan dari pembentukan formil ini adalah :

1) Terbentuknya cara-cara berpikir yang baik, dapat menggunakan metode berpikir yang tepat, serta mengambil kesimpulan yang logis.

2) Terbentuknya minat yang kuat, yang sejajar dengan terbentuknya pengertian. Minat merupakan kecenderungan jiwa ke arah sesuatu karena sesuatu itu mempunyai arti bukan karena terpaksa.

3) Terbentuknya sikap (pendirian) yang tepat, Sikap terbentuk bersamasama dengan minat. Sikap yang tepat, ialah bagaimana seharusnya seseorang itu bersikap terhadap agamanya, nilai-nilai yang ada di 
dalamnya, terhadap nilai-nilai kesulitan, dan terhadap orang lain yang berpendapat lain.

2. Materil

Pembentukan materil sebenarnya telah dimulai sejak masa kanak-kanak, jadi sejak pembentukan taraf pertama, namun barulah pada taraf kedua ini (masa intelek dan masa sosial). Anak-anak yang telah cukup besar dan mampu menepis mana yang berguna dan mana yang tidak, harusnya dilatih berpikir kritis.

3. Intensil

Pembentukan intensil yaitu pengarahan, pemberian arah, dan tujuan yang jelas bagi pendidikan Islam, yaitu terbentuknya kepribadian muslim. Untuk membentuk ke arah mana kepribadian itu akan dibawa, maka di samping pemberian pengetahuan juga tentang nilai-nilai. Jadi, bukan hanya merupakan pemberian perlengkapan, tetapi juga pemberian tujuan ke arah mana perlengkapan itu akan dibawa. Pada segi lain, pembentukan intensil ini lebih progresif lagi, yaitu nilai-nilai yang mengarahkan sudah harus dilaksanakan dalam kehidupan. Mungkin masih dengan pengawasan orang tua, tetapi lebih baik lagi jika atas keinsyafan sendiri. Ahmad D. Marimba (1989:88).

Dari uraian di atas, dapat disimpulkan bahwa yang diberikan oleh orang tua dalam keluarga, baik dalam bentuk bimbingan, pendidikan, maupun perhatian merupakan salah satu upaya yang dapat membentuk kepribadian anak atau kepribadian siswa. Selain itu, terdapat pula cara lain yang dapat dipergunakan dalam membentuk kepribadian, yaitu pembiasaan, yang bertujuan untuk menanamkan kecakapan-kecakapan berbuat, mengucapkan sesuatu dengan tepat, dan dapat dikuasai oleh si anak serta mempunyai implikasi yang mendalam bagi pembentukan kepribadian pada tahap selanjutnya.

\section{Kepribadian}

Pengertian Kepribadian 
Dalam pandangan umum kata-kata kepribadian sering dikonotasikan dengan sifat, watak ataupun tingkah laku.

Menurut tinjauan buku-buku psikologi, kepribadian berasal dari kata persona (Yunani), yang berarti kedok atau topeng. Di zaman Yunani kuno para pemain sandiwara bercakap-cakap atau berdialog menggunakan semacam penutup muka (topeng) yang dinamakan persona. Dari kata tersebut, kemudian dipindahkan ke bahasa Inggris menjadi personality (kepribadian). (Agus Sujanto, 2009 : 10).

Definisi kepribadian secara terminologi menurut beberapa ahli yaitu:

Allport dalam buku Agus Sujanto, mendefinisikan "personality is the dynamic organization within the individual of these psychopysical system, that determines his unique adjusment to his environment". Artinya : kepribadian adalah organisasi dinamis dalam diri individu yang terdiri atas sistem psikopisik yang menentukan penyesuaian dirinya yang khas terhadap lingkungannya. (Agus Sujanto, 2009 : 94).

Sedangkan menurut Koentjaningrat mendefinisikan "kepribadian sebagai perbedaan tingkah laku atau tindakan-tindakan dari tiap-tiap individu manusia”. (Koentjaningrat, 1990 : 102)

Menurut Ngalim Purwanto mengutip pendapat dari Sartain, "kepribadian adalah sesuatu yang nyata dan dapat dipercaya tentang individu, untuk menggambarkan bagaimana dan apa sebenarnya individu itu". (Ngalim Purwanto, $2007:$ 154)

Wikipedia (Dalam http://en.wikipedia.org/wiki/Gordon Allport/ didownload tanggal 18 Maret 2016). Menjelaskan definisi Kepribadian menurut Gordon Willard Allport "Kepribadian manusia adalah organisasi yang dinamis dari system psikofisik dalam individu yang turut menentukan cara-caranya yang unik atau khas dalam menyesuaikan diri dengan lingkungannya".

Terkait dengan definisi yang dikemukakan oleh para ahli di atas, penulis dapat simpulkan bahwa kepribadian adalah totalitas dari psikologis yang kompleks dari individu yang nampak dalam tingkah laku sehari-hari atau bisa juga disebut kepribadian. 
Anak

Menurut The Minimum Age Convention Nomor 138 tahun 1973, pengertian tentang “anak adalah seseorang yang berusia 15 tabun ke bawab”. Sebaliknya, dalam Convention on The Right Of the Child tahun 1989 yang telah diratifikasi pemerintah Indonesia melalui Keppres Nomor 39 Tahun 1990 disebutkan bahwa "anak adalab mereka yang berusia 18 tahun ke bawab". Sementara itu, UNICEF mendifenisikan "anak sebagai penduduk yang berusia antara 0 sampai dengan 18 tahun”. Undang-Undang RI Nomor 4 tahun 1979 tentang Kesejahteraan Anak, menyebutkan bahwa "anak adalah mereka yang belum berusia 21 tahun dan belum menikah". Sedangkan Undang-undang Perkawinan menetapkan batas usia 16 tahun (Huraerah, 2006: 19).

Undang No. 12 tahun 1948) mendefinisikan "anak adalab orang lakilaki atau perempuan berumur 14 tabun kebawah". (Prints, Darwan 2003:3). Yang dimaksud dengan anak dalam konvensi PBB (pasal 1), "adalah orang yang berusia dibawah 18 tahun kecuali berdasarkan Undang-Undang yang berlaku dalam bagi anak ditentukan bahwa usia dewasa dicapai lebih awal".

Maka, secara keseluruhan dapat dilihat bahwa rentang usia anak terletak pada skala 0 sampai dengan 21 tahun. Penjelasan mengenai batas usia 21 tahun ditetapkan berdasarkan pertimbangan kepentingan usaha kesejahteraan sosial, kematangan pribadi dan kematangan mental seseorang yang umumnya dicapai setelah seseorang melampaui usia 21 tahun.

\section{Tinjauan Tentang Lingkungan Keluarga Dan Implikasinya Terhadap Pembentukan Kepribadian Anak}

Lingkungan sangat menentukan proses pembentukan karakter diri seseorang. Lingkungan yang positif dapat membentuk pribadi yang berkarakter positif, sebaliknya lingkungan yang negatif dan tidak sehat dapat membentuk seseorang menjadi pribadi yang negatif.

Lingkungan keluarga merupakan sebuah basis awal kehidupan bagi setiap manusia. Keluarga menyiapkan sarana pertumbuhan dan perkembangan sekaligus pembentukan kepribadian anak sejak dini. Dengan kata lain kepribadian 
anak tergantung pada pemikiran dan perlakuan kedua orang tua dan lingkungannya.

Untuk lebih jelasnya, Berikut Penulis tuangkan secara terperinci tentang lingkungan keluarga dan implikasinya terhadap pembentukan kepribadian anak.

\section{Lingkungan Keluarga}

Di Indonesia sendiri, keluarga telah diatur dalam berbagai peraturan atau undang-undang RI nomor 10 tahun 1992 mendefinisikan keluarga sebagai berikut : "Keluarga merupakan wahana pertama seorang anak mendapatkan pengetahuan dan keterampilan yang diperlukan bagi kelangsungan hidupnya”.

Selanjutnya Gunarsa (2009:5) menjelaskan bahwa :

"lingkungan keluarga merupakan lingkungan pertama yang mula-mula memberikan pengaruh yang mendalam bagi anak. Dari anggota-anggota keluarganya (ayah, ibu, dan saudara-saudaranya) anak memperoleh segala kemampuan dasar, baik intelektual maupun sosial. Setiap sikap, pandangan, dan pendapat orang tua atau anggota keluarga lainnya akan dijadikan contoh oleh anak dalam berperilaku".

Berdasarkan pendapat tersebut dapat disimpulkan bahwa lingkungan keluarga merupakan lingkungan pendidikan pertama yang sangat penting dalam membentuk pola kepribadian anak. Karena di dalam keluarga, anak pertama kali mendapat pengetahuan tentang nilai dan norma.

Selanjutnya, Orang tua memegang peranan penting dalam hal baik buruknya pembentukan kepribadian anak sebagaimana yang telah di sabdakan Nabi Muhammad Saw yang artinya: "Setiap anak dilabirkan dalam keadaan suci maka kedua orang tualah yang menjadikan anak tersebut beragama Yabudi, Nasrani, Majusi”. (H.R. Bukhari)

Dengan memperhatikan hadits di atas maka fungsi orang tua dalam mendidik anaknya sangat besar pengaruhnya terhadap perkembangan kepribadian seorang anak di kemudian hari.

Bertolak dari uraian di atas Zakiah Darajat mengatakan bahwa : akibat yang mungkin terjadi pada anak-anak apabila ia kurang diperhatikan 
itu banyak sekali, antara lain akan terganggu kesehatan mentalnya. Di antara kelakuan yang dapat terlihat dengan nyata ialah :

a) Suka memperhatikan gerak gerik orang tua, banyak tanya seperti pergi kemana, dan mana kadang-kadang menyakitkan orang tua

b) Sering melakukan hal-hal yang menarik perhatian untuk memperoleh kasih sayang

c) Kelakuan dan sikap menunjukan bahwa ia benci pada orang, acuh tak acuh dsb. (Zakiah Darajat, 1988: 80).

Selanjutnya Rasulullah Saw juga pernah menegaskan dalam hadist yang berbunyi:

"Dari Ibnu Umar. Ra berkata saya telah mendengar Rasulullah Saw bersabda: kamu sekalian adalah pemimpin dan kamu akan ditanya kepemimpinanmu. Seorang imam akan ditanya tentang kepemimpinan, seorang laki-laki sebagai pemimpin terhadap keluarga dan bertanggung jawab terhadap yang dipimpinnya dan istri sebagai ibu rumah tangga bertanggung jawab atas rumah tangganya dan pelayan sebagai penjaga kekayaan majikannya dan akan bertanggung jawab dengan pemeliharaan, maka kamu sekalian adalah sebagai pemimpin dan orang-orang bertanggung jawab terhadap yang dipimpinnya". (Zuhairini, 1983:26).

Dengan memperhatikan hadits di atas maka fungsi orang tua dalam mendidik anaknya sangat besar pengaruhnya terhadap perkembangan kepribadian seorang anak di masa depan. Hal ini semakin diperkuat dengan firman allah swt dalam firmannya:
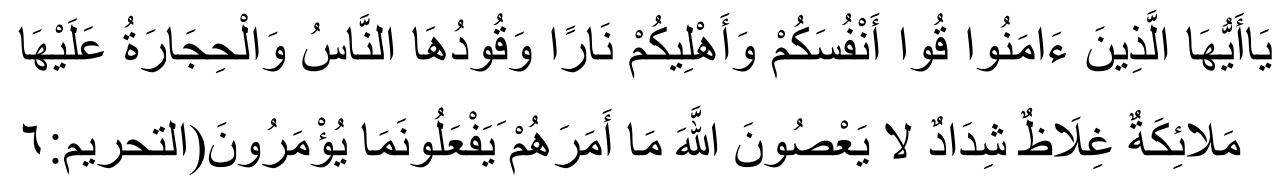

Artinya: "Hai orang-orang yang beriman, peliharalah dirimu dan keluargamu dari api neraka yang bahan bakarnya adalah manusia dan batu; penjaganya malaikat-malaikat yang kasar, keras, dan tidak mendurbakai Allah terhadap apa yang diperintabkan-Nya kepada mereka dan selalu mengerjakan apa yang diperintabkan”.(DEPAG RI, ALQuran dan Terjemahannya 1978:560). 
Dari uraian tersebut dapat disimpulkan bahwa lingkungan keluarga sangat berimplikasi terhadap perkembangan serta pembentukan kepribadian setiap anak. Karna setiap keluarga(orang tua) memiliki cara-cara tersendiri dalam mengaplikasikan rasa cinta dan kasih sayang terhadap anak-nya baik dalam hal materi maupun hal lain yang berhubungan dengan perkembangan kepribadian setiap anak dimasa depannya apakah akan menjadi pribadi yang positif ataukah sebaliknya tergantung dari cara masing-masing orang tua dalam membimbing serta mendidik mereka.

\section{Fungsi Keluarga Dalam Pembentukan Kepribadian Anak}

Fungsi keluarga ialah memelihara, merawat dan melindungi anak dalam rangka sosialisasinya agar mereka mampu mengendalikan diri dan berjiwa sosial untuk membentuk mereka menjadi pribadi yang didambakan setiap orang.

Menurut MI Soelaeman fungsi-fungsi keluarga diantaranya adalah :

a. Fungsi Edukatif

Sebagai suatu unsur dari tingkat pusat pendidikan, merupakan lingkungan pendidikan yang pertama bagi anak. Dalam kedudukan ini, adalah suatu kewajaran apabila kehidupan keluarga sehari-hari pada saatsaat tertentu terjadi situasi pendidikan yang dihayati oleh anak dan diarahkan pada perbuatan-perbuatan yang sesuai dengan tujuan pendidikan.

b. Fungsi Sosialisasi

Melalui interaksi dalam keluarga anak mempelajari pola-pola tingkahlaku, sikap, keyakinan, cita-cita serta nilai-nilai dalam masyarakat dalam rangka pengembangan kepribadiannya. Dalam rangka melaksanakan fungsi sosialisasi ini, keluarga mempunyai kedudukan sebagai penghubung antara anak dengan kehidupan sosial dan norma-norma sosial yang meliputi penerangan, penyaringan dan penafsiran ke dalam bahasa yang dimengerti oleh anak.

c. Fungsi Protektif 
Fungsi ini lebih menitik beratkan dan menekankan kepada rasa aman dan terlindungi apabila anak merasa aman dan terlindungi barulah anak dapat bebas melakukan penjajagaan terhadap lingkungan.

d. Fungsi Afeksional

Yang dimaksud dengan fungsi afeksi adalah adanya hubungan sosial yang penuh dengan kemesraan dan afeksi. Anak biasanya mempunyai kepekaan tersendiri akan iklim-iklim emosional yang terdapat dalam keluarga kehangatan yang terpenting bagi perkembangan kepribadian anak. e.Fungsi Religius

Keluarga berkewajiban memperkenalkan dan mengajak anak serta keluarga pada kehidupan beragama. Sehingga melalui pengenalan ini diharapkan keluarga dapat mendidik anak serta anggotanya menjadi manusia yang beragama sesuai dengan keyakinan keluarga tersebut.

f. Fungsi Ekonomis

Fungsi keluarga ini meliputi pencarian nafkah, perencanaan dan pembelanjaannya. Pelaksanaanya dilakukan oleh dan untuk semua anggota keluarga, sehingga akan menambah saling mengerti, solidaritas dan tanggung jawab bersama.

g. Fungsi Rekreatif

Suasana keluarga yang tentram dan damai diperlukan guna mengembalikan tenaga yang telah dikeluarkan dalam kehidupan sehari-hari.

h. Fungsi Biologis

Fungsi ini berhubungan dengan pemenuhan kebutuhan-kebutuhan biologis keluarga, diantaranya kebutuhan seksual. Kebutuhan ini berhubungan dengan pengembangan keturunan atau keinginan untuk mendapatkan keturunan. Selain itu juga yang termasuk dalam fungsi biologis ini yaitu perlindungan fisik seperti kesehatan jasmani, dan kebutuhan jasmani yaitu dengan terpenuhinya kebutuhan sandang, pangan dan papan akan mempengaruhi kepada jasmani setiap anggota keluarga.

Pembentukan kepribadian anak akan sangat dipengaruhi oleh bagaimana lingkungan keluarganya. Karenanya, keharmonisan keluarga menjadi sesuatu hal mutlak untuk diwujudkan, misalnya suasana rumah. 
Ketika keikhlasan, kejujuran dan kerjasama kerap diperlihatkan oleh masingmasing anggota keluarga dalam hidup mereka setiap hari, maka hampir bisa dipastikan hal yang sama juga akan dilakukan anak yang bersangkutan.

Sebaliknya, anak akan sangat sulit menumbuhkan dan membiasakan berbuat dan bertingkah laku baik manakala di dalam lingkungan keluarga (sebagai ruang sosialisasi terdekat, baik fisik maupun psikis) selalu diliputi dengan pertikaian, pertengkaran, ketidakjujuran, kekerasan, baik dalam hubungan sesama anggota keluarga ataupun dengan lingkungan sekitar rumah. Kompasiana ( dalam http://www.kompasiana.com/srisafitri/perandan-fungsi-keluarga-dalam-pembentukan-kepribadian-anak $\backslash$ didownload tanggal 14 maret 2016).

\section{Peran Kedua Orang Tua Dalam Mewujudkan Kepribadian Anak}

Diantaranya adalah :

a. Kedua orang tua harus mencintai dan menyayangi anak-anaknya. Ketika anak-anak mendapatkan cinta dan kasih sayang cukup dari kedua orang tuanya, maka pada saat mereka berada di luar rumah dan menghadapi masalah-masalah baru mereka akan bisa menghadapi dan menyelesaikannya dengan baik. Sebaliknya jika kedua orang tua terlalu ikut campur dalam urusan mereka atau mereka memaksakan anakanaknya untuk menaati mereka, maka perilaku kedua orang tua yang demikian ini akan menjadi penghalang bagi kesempurnaan kepribadian mereka

b. Kedua orang tua harus menjaga ketenangan lingkungan rumah dan menyiapkan ketenangan jiwa anak-anak. Karena hal ini akan menyebabkan pertumbuhan potensi dan kreativitas akal anak-anak yang pada akhirnya keinginan dan Kemauan mereka menjadi kuat dan hendaknya mereka diberi hak pilih

c. Saling menghormati antara kedua orang tua dan anak-anak. Hormat di sini bukan berarti bersikap sopan secara lahir akan tetapi selain ketegasan kedua orang tua, mereka harus memperhatikan keinginan dan permintaan alami dan fitri anak-anak. Saling menghormati artinya dengan mengurangi 
kritik dan pembicaraan negatif terkait dengan kepribadian dan perilaku mereka serta menciptakan iklim kasih sayang dan keakraban, dan pada waktu yang bersamaan kedua orang tua harus menjaga hak-hak hukum mereka yang terkait dengan diri mereka dan orang lain. Kedua orang tua harus bersikap tegas supaya mereka juga mau menghormati sesamanya

d. Mewujudkan kepercayaan. Menghargai dan memberikan kepercayaan terhadap anak-anak berarti memberikan penghargaan dan kelayakan terhadap mereka, karena hal ini akan menjadikan mereka maju dan berusaha serta berani dalam bersikap. Kepercayaan anak-anak terhadap dirinya sendiri akan menyebabkan mereka mudah untuk menerima kekurangan dan kesalahan yang ada pada diri mereka. Mereka percaya diri dan yakin dengan kemampuannya sendiri. Dengan membantu orang lain mereka merasa keberadaannya bermanfaat dan penting

e. Mengadakan perkumpulan dan rapat keluarga (kedua orang tua dan anak). Dengan melihat keingintahuan fitrah dan kebutuhan jiwa anak, mereka selalu ingin tahu tentang dirinya sendiri. Tugas kedua orang tua adalah memberikan informasi tentang susunan badan dan perubahan serta pertumbuhan anak-anaknya terhadap mereka. Selain itu kedua orang tua harus mengenalkan mereka tentang masalah keyakinan, akhlak dan hukum-hukum fikih serta kehidupan manusia. Jika kedua orang tua bukan sebagai tempat rujukan yang baik dan cukup bagi anak-anaknya maka anak-anak akan mencari contoh lain baik atau buruk dan hal ini akan menyiapkan sarana penyelewengan anak.

f. Memberikan peringatan dengan kata-kata yang mengandung petunjuk dan nasehat yang tulus Al Qur'an telah menegaskan pengertian ini dalam banyak ayatnya, dan berulang kali menyebutkan manfaat dari peringatan dengan kata-kata yang mengandung petunjuk dan nasehat yang tulus, di antaranya:

"Sesungguhnya pada yang demikian itu benar-benar terdapat peringatan bagi orang-orang yang mempunyai akal atau yang menggunakan pendengarannya, sedang dia menyaksikannya.” (Q.S Qaaf, 50:37) 
"Dan tetaplah memberi peringatan, karena sesungguhnya peringatan itu bermanfa'at bagi orang-orang yang beriman”.(Q.S Dzariyat: 51:55)

Nasehat sangat berperan dalam menjelaskan kepada anak tentang segala hakekat serta menghiasinya dengan akhlak mulia. Nasehat orang tua jauh lebih baik dari pada orang lain, karena orang tualah yang selalu memberikan kasih sayang serta contoh perilaku yang baik kepada anaknya.

(dalam https://www.google.com/search?q=peran+kedua+orang+tua+dalam+e wujudkan + kepribadian + anak\&ie $=u t f-8 \& o e=u t f-8 \backslash$ didownload tanggal 14 maret 2016).

\section{Persoalan Keluarga Dan Implikasinya Terhadap Pembentukan Kepribadian} Anak

Dinamika kehidupan yang terus berkembang membawa konsekuensi-konsekuensi tertentu terhadap kehidupan keluarga. Banyaknya tuntutan kehidupan yang menerpa keluarga serta bergesernya nilai-nilai dan pandangan tentang fungsi dan peranan anggota keluarga menyebabkan terjadinya berbagai perubahan mendasar tentang kehidupan keluarga.

Terlepas dari bentuk dan wujud perubahan-perubahan yang terjadi, pergeseran-pergeseran tersebut membuat semakin kompleksnya permasalahan-permasalahan yang dialami keluarga yang pada gilirannya akan memberikan dampak tertentu terhadap pembentukan kepribadian anak. Untuk dapat membentuk pribadi yang sehat dan sejalan dengan nilai-nilai yang dianut masyarakat, dengan sendirinya anak perlu melakukan penyesuaian. Permasalahan utama keluarga yang lazim dialaminya, yakni masalah orang tua yang bekerja dan perceraian. (Dalam https://www.google.com/search?q=persoalan + keluarga + dan + implikasiny $+\mathrm{t}$ $\underline{\text { erhadap }+ \text { pembentukan }+ \text { kepribadian }+ \text { anak\&ie }=u t f-8 \& o e=u t f 8 \backslash \text { didownload }}$ tanggal 14 maret 2016).

\section{Faktor-Faktor Yang Mempengaruhi Terbentuknya Kepribadian Anak}

Banyak para ahli yang berusaha mengungkapkan faktor - faktor pembentuk kepribadian sejak zaman dahulu. Berdasarkan hasil penelitian lahirlah beberapa aliran tentang kepribadian, antara lain sebagai berikut : 
1) Nativisme : Kepribadian ditentukan oleh faktor pembawaan seperti bakat, kemauan dan kecerdasan. Tokoh aliran nativisme yaitu Thomas Hobbes dan J.J.Rousseau.

2) Empirisme : kepribadian ditentukan oleh pengalaman atau lingkungannya. Tokoh aliran ini adalah John Locke

3) Konvergensi : Aliran ini merupakan perpaduan dari kedua aliran diatas yang menyatakan bahwa hasil perpaduan antara pembawaan dan pengalaman.

Kepribadian umum (modal personality) adalah kepribadian yang ada pada sebagian besar warga suatu masyarakat, yang disebut juga dengan istilah watak umum.

Pembentukan kepribadian seseorang berlangsung dalam suatu proses yang disebut dengan sosialisasi, yaitu suatu proses dimana seseorang menghayati (mendarah-dagingkan-internalize) norma-norma kelompok dimana ia hidup sehingga muncullah dirinya yang "unik".

Bagaimana Kepribadian itu berkembang ? ada tiga faktor yang menentukan dalam perkembangan kepribadian :

a. Faktor bawaan

Unsur ini terdiri dari bawaan genetik yang menentukan diri fisik primer (warna, mata, kulit), selain itu juga kecenderungan- kecenderungan dasar misalnya kepekaan, penyesuaian diri.

Contoh :

- Rambut ikal seorang anak karena salah satu orang tua berambut ikal.

- Bakat anak menurun dari orang tua

- Potensi diri anak (IQ)

b. Faktor lingkungan 
Faktor lingkungan seperti sekolah, atau Lingkungan sosial/budaya seperti teman, guru. Dapat mempengaruhi terbentuknya kepribadian.

Contoh :

- Perluasan wawasan

- pendidikan formal/informal

- pergaulan/perjalanan

c. Interaksi antara bawaan serta lingkungan

Interaksi yang terus menerus antara bawaan serta lingkungan menyebabkan timbulnya perasaan Aku/Diriku dalam diri seseorang. Contoh :

- Pengalaman masa kanak-kanak anak yang sering dipukul maka cenderung pada saat dewasa menjadi sadis/kejam.

- Konsep diri individu dapat dipengaruhi oleh beberapa faktor diantaranya adalah : Harapan dari orang tua, Keadaan fisik seseorang, Sikap anggota keluarga, Kematangan biologis, Kesempatan untuk menempuh pendidikan, Tuntutan sekolah, Agama dan kepercayaan, Pengaruh dan pendapat teman sebaya, Keadaan ekonomi keluarga, Masalah/problem keluarga, Sikap teman sebaya.

Sedangkan menurut Horton dan Chyestr L. Hunt (1999), faktorfaktor yang mempengaruhi terbentuknya kepribadian seseorang antara lain:

1) Faktor keturunan (Hereditas) warisan Biologis.

2) Faktor lingkungan alam (Natural environmental).

3) Faktor kelompok (group).

4) Faktor kebudayaan khusus.

5) Faktor pengalaman unik.

\section{Fungsi Lingkungan Keluarga Dalam Pembentukan Kepribadian Anak}

Dalam proses pembentukan kepribadian telah dibahas mengenai faktorfaktor yang berperan di dalamnya. Dalam hubungan saling pengaruh mempengaruhi, akan terlihat bahwa seorang anak dalam proses pembentukan kepribadian dirinya 
memperlihatkan sifat-sifat yang tertuju pada lingkungan, khususnya lingkungan keluarga, memperlihatkan reaksi yang dibentuk atas dasar sifat-sifat, penampilan anak dan pengolahan lingkungan dengan proses perubahannya.

Lingkungan keluarga yang berubah juga dapat memberikan perangsang pada seseorang yang sangat mempengaruhi terhadap perkembangannya, khususnya perkembangan pembentukan kepribadian. Lingkungan yang baik adalah lingkungan yang mencapai taraf kecanggihan tertentu sehingga siterdidik dapat mereproduksi diri secara terus menerus, mengatasi krisis-krisis yang dialaminya melalui mekanisme-mekanisme yang ada dalam dirinya. Sehingga dengan demikian perkembangan pembentukan kepribadian seorang anak memberikan penampilan kepada lingkungan yang merubahnya.

Dari uraian tersebut terlihat suatu hubungan timbal balik antara seorang anak dengan konstitusi yang berkembang terus dan lingkungan yang merubahnya.(dalamhttps://salehlapadi.wordpress.com/2007/02/25/peranlingku ngan-keluarga-dalam-membentuk-kepribadiananak/didownloadtanggal14 maret 2016),

Oleh karena itu, tidaklah berlebihan jika penulis simpulkan bahwa implikasi lingkungan keluarga sangat mempengaruhi dalam proses pembentukan kepribadian anak. Untuk dapat memahami kepribadian seseorang, kita tidak dapat melepaskan diri dari lingkungan dimana manusia tumbuh dan berkembang.

\section{Lingkungan Keluarga Siswa di Sekitar Dan Implikasinya Terhadap Pembentukan Kepribadian Anak}

Seperti yang telah diuraikan pada bab Sebelumnya bahwa Lingkungan adalah semua kondisi yang ada di sekitar manusia yang dapat memberikan kesan/pengaruh terhadap perkembangan psikis dan kehidupan manusia itu sendiri. Dalam hal ini lingkungan yang dimaksud adalah lingkungan pendidikan dan lingkungan keluarga.

Lingkungan Kecamatan Keruak Lombok Timur ditinjau dari segi lokasinya memiliki lokasi yang sangat berimplikasi terhadap pembentukan kepribadian anak karena lokasinya yang masih asri dan nyaman, serta dekat dengan perkampungan warga (tempat tinggal siswa) juga dikelilingi oleh 
pematang sawah yang membuat pendidik dan para peserta didik merasa nyaman saat aktifitas belajar mengajar sedang berlangsung, sehingga dapat mengoptimalkan daya tangkap siswa terhadap materi yang disampaikan oleh pendidik.

Pernyataan ini sesuai dengan hasil wawancara penulis dengan Salah Seorang Staf yang mengatakan bahwa para orang tua murid di desa Selebung Ketangga semakin sadar akan pentingnya pendidikan dan betapa pentingnya menyekolahkan anak-anaknya di madrasah karena beranggapan bahwa, selain mendapatkan pengetahuan umum juga mendapatkan pengetahuan tentang agama islam serta hukum-hukum yang terkandung didalamnya. Hal ini dapat dirasakan oleh beberapa wali murid (orang tua siswa) dengan adanya perubahan Kepribadian (etika) pada anaknya dalam kesehariannya dilingkungan keluarga dan dengan teman sepermainannya, anehnya anak yang awalnya suka membantah perintah orang tua sekarang jadi patuh dan penurut, tutur pak ikhsan (orang tua murid) setelah beberapa bulan menimba ilmu di Kecamatan Keruak pada salah seorang staf di Madrasah tersebut.

Selain pendapat tersebut penulis juga melakukan wawancara terstruktur dengan beberapa wali murid (kelas XIPS) dengan mengunjungi rumah mereka, adapun hasil wawancara penulis dengan salah seorang wali murid yang rata-rata memiliki keluhan yang sama seputar kepribadian (akhlak) anak-anak mereka.

"Bingung saya mba, tutur pak hardi (wali murid salah seorang siswa) pada penulis, saya benar-benar bingung sama kelakuan anak saya yang semakin hari makin bandel saja. Dia minta dibeliin motor saya belikan minta handphoone apalagi . pokoknya semua yang dia pengen selalu saya turuti, tapi kelakuannya malah semakin parah mba disurub solat nda mau puasa apalagi”.

Dari beberapa orang tua murid yang penulis wawancarai salah seorang ibu (wali murid) menceritakan tentang kepribadian anaknya yang benar-benar sesuai dengan dambaan semua orang tua. Setelah mendengarkan penuturan dari ibu tersebut, Penulis kemudian menanyakan tentang cara beliau mendidik anaknya sehingga sesuai dengan harapan si ibu.

"Saya si nda terlalu memaksakan kehendak sama anak dek", tutur si ibu pada penulis dengan lantang. Anak itu sebenarnya cerminan orang tua mereka, baik buruknya 
kepribadian anak tergantung warisan dari keduannya (ayah dan ibu)". Pendapat tersebut diperkuat dengan pendapat Abin Syamsuddin yang mengatakan bahwa "Pranata keluarga merupakan titik awal keberangkatan sekaligus sebagai modal awal perjalanan bidup mereka”. (Abin Syamsuddin, 1993).

Mempelajari hasil wawancara di atas penulis dapat simpulkan bahwa kepribadian seorang anak memang tergantung dari kedua orang tua mereka karena baik buruknya seorang anak terletak pada cara orang tua didalam mendidik puta \inya, apakah dengan cara memanjakan mereka dengan harta yang berlimpah, memberikan kasih sayang yang tulus, ataukah bersikap acuh tak acuh terhadap mereka tergantung dari pola pikir \sudut pandang dari masing-masing anda sebagai orang tua, karena pendidikan dilingkungan keluarga akan menghasilkan pembentukan kepribadian yang beragam terhadap masing-masing anak.

Perlu diperhatikan bahwa, kondisi sosial-ekonomi masing-masing orang-tua murid yang berada di desa selebung ketangga, diamati dari hasil observasi peneliti bahwa warga di sekitar Kecamatan Keruak. Sebagian besar mata pencahariannya adalah, PNS, Guru Honorer, Pedagang, Petani dan Buruh. Baik yang menetap maupun yang pergi mengadu nasip ke luar negeri, maka hal ini secara tidak langsung berimplikasi terhadap pembentukan kepribadian anak.

Keadaan Sosial ekonomi warga disekitar Kecamatan Keruak. Sesuai dengan wawancara penulis dengan RT dan RW setempat yang memberikan keterangan bahwa kondisi sosial ekonomi warga sekitar masih dalam kategori ekonomi menengah ke bawah. Hal ini sangat berimplikasi terhadap kehidupan dan kualitas sumberdaya manusia maupun terhadap pembentukan kepribadian anak sehingga berdampak pada peningkatan kualitas pendidikan.

Di antara beberapa implikasi yang dapat dilihat oleh penulis sesuai hasil observasi selama 3 bulan adalah adanya peningkatan gaya hidup siswa yang disebabkan adanya implikasi dari sebagian orang tua siswa yang pergi mengadu nasip di luar negeri. Dengan keberhasilan yang diraihnya sebagian dari orang tua siswa banyak mengirimkan untuk anak-anak mereka HP (Handphoone) sebagai hadiah tanpa mempertimbangkan implikasinya bagi kepribadian dan ketekunan anak dalam meraih prestasinya di Madrasah. Bagi seorang anak yang selalu berada 
dalam pengawasan orang tuanya, mungkin hal tersebut bukanlah sesuatu hal yang perlu dikhawatirkan. Sebaliknya pemberian rasa puas kepada anak tanpa pengawasan kedua orang tua akan mengakibatkan anak larut dalam kesenangankesenangan dan kepuasan, sehingga pendidikannya harus terabaikan.

Mengingat implikasi lingkungan keluarga sangat besar terhadap pembentukan kepribadian anak didik. Maka diperlukan lingkungan yang sehat, bersih dan harmonis sehingga siswa dapat merasakan kedamaian dan kenyamanan, serta kesehatan lingkungan dimana mereka menimba ilmu pengetahuan. Hal ini perlu diperhatikan oleh semua pihak yang terlibat didalamnya untuk memberikan bimbingan dan pengetahuan secara umum bagi warga sekitar, maupun bagi instansi terkait.

Akhirnya penulis simpulkan sesuai dengan hipotesis yang penulis uraikan pada bab sebelumnya bahwa hasil penelitian yang dilakukan sesuai dengan dugaan sementara penulis yaitu dilihat dari hasil observasi penulis selama tiga bulan penulis akhirnya dapat simpulkan bahwa lingkungan keluarga sangat berimplikasi terhadap pembentukan kepribadian anak pada Siswa kelas X IP di Kecamatan Keruak.

\section{Deskrifsi Tentang Kendala-Kendala Yang Di Alami Penulis Dalam Pelaksanaan Penelitian}

Pelaksanaan Penelitian yang berlangsung di NW Selebung Ketangga secara umum berjalan dengan baik dan lancar. Namun dalam beberapa hal penulis menemukan beberapa hambatan baik dalam diri penulis maupun hambatan dari luar. Diantaranya adalah :

- Proses adaptasi penulis dengan lingkungan dan budaya madrasah yang cukup lama

- Kurangnya pengalaman penulis dalam menyingkapi segala permasalahan yang timbul dilapangan

- Penulis mengalami beberapa kesulitan dalam menarik simpati warga dihari pertama penulis berkunjung di salah satu rumah wali murid disekitar Madrasah 
- penulis yang kekurangan buku pegangan dan kurang mampu untuk membeli buku penunjang serta di perpustakaan tidak tersedia sesuai dengan refrensi yang penulis butuhkan untuk kesempurnaan penulisan laporan penelitian.

\section{Catatan Akhir}

Setelah Penulis Menguraikan secara keseluruhan tentang judul skripsi, "Implikasi Lingkungan Keluarga Terhadap Pembentukan Kepribadian Anak Pada Siswa Kelas X IPS di Tahun Pelajaran 2015\2016”.

Melalui metode Kualitatif menggunakan pendekatan Naturalistik dengan beberapa metode dalam pengumpulan data dimulai dari penyusunan proposal penelitian, membuat pedoman wawancara, mengumpulkan beberapa data dari dokumen madrasah dan dari beberapa partisipan (narasumber), kemudian menganalisis data dengan trianggulasi, serta mengabadikan hasil-hasil observasi lapangan dengan menggunakan metode dokumentasi, dan sampai pada penulisan laporan hasil penelitian lapangan dengan menggunakan metode deduktif-induktif. Akhirnya penulis dapat simpulkan mengenai konten dari hasil penelitian yang dilakukan, berikut pemaparannya :

Lingkungan Keluarga merupakan lingkungan pendidikan pertama yang sangat penting dalam membentuk pola kepribadian anak. Karena di dalam keluarga, anak pertama kali mendapat pengetahuan tentang nilai dan norma. Dan kedua Orang tualah yang memegang peranan penting dalam hal baik buruknya pembentukan kepribadian anak sebagaimana yang telah di sabdakan Nabi Muhammad Saw yang artinya: "Setiap anak dilabirkan dalam keadaan suci maka kedua orang tualah yang menjadikan anak tersebut beragama Yabudi, Nasrani, Majusi”. (H.R. Bukhari)

Dengan memperhatikan hadits di atas maka fungsi orang tua dalam mendidik anaknya sangat besar pengaruhnya terhadap perkembangan kepribadian seorang anak di kemudian hari. Seperti yang dituturkan oleh salah seorang wali murid yang mengatakan bahwa. Anak itu sebenarnya cerminan orang tua mereka, baik buruknya kepribadian anak tergantung warisan dari keduannya (ayah dan ibu)”. Pendapat tersebut diperkuat dengan pendapat Abin Syamsuddin yang mengatakan bahwa 
"Pranata keluarga merupakan titik awal keberangkatan sekaligus sebagai modal awal perjalanan hidup mereka”. (Abin Syamsuddin, 1993).

Sehingga penulis dapat menarik simpulan bahwa, Konsepsi Islam tentang lingkungan keluarga sangat positif. Lingkungan yang indah, harmonis, sehat, nyaman dan tentram akan mempengaruhi perasaan dan jiwa anak didik yang dapat membentuk kepribadian mereka menjadi pribadi yang sopan dan patuh terhadap orang tua, serta peduli terhadap sesamanya, baik dilingkungan keluarga, madrasah, masyarakat ataupun lingkungan sosial lainnya yang dapat memberi harapan baru bagi generasi berikutnya.

\section{Daftar Rujukan}

Dilihatya http://dilihatya.com/2411/pengertian-implikasi-menurut-para-ahli/) didownload tanggal 14 maret 2016.

https://www.google.com/search?q=persoalan+keluarga+dan+implikasiny+terhada p+pembentukan+kepribadian+anak\&ie $=u t f-8 \& o e=u t f 8 \backslash$ didownload tanggal 14 maret 2016.

https://salehlapadi.wordpress.com/2007/02/25/peranlingkungan-keluarga-dalammembentuk-kepribadiananak/ didownloadtanggal14 maret 2016.

http://www.kompasiana.com/srisafitri/peran-dan-fungsi-keluarga-dalampembentukan-kepribadian-anak\didownload tanggal 14 maret 2016.

https://www.google.com/search?q=peran+kedua+orang+tua+dalam+ewujudkan+k epribadian+anak\&ie=utf-8\&oe=utf-8 didownload tanggal 14 maret 2016.

http://www.kajianpustaka.com/2012/11/definisi-fungsi-dan-bentuk-

keluarga.html didownload tanggal 14 januari 2016

http://aroxx.blogspot.com/2013/12/pengertiandefinisi-lingkungan-keluarga.html didownload tanggal 14 januari 2016

http://yogirahma.wordpress.com/2014/04/11/makalah-pengertian-fungsi-danjenis-lingkungan-pendidikan/ didownload tanggal 10 desember 2015 
Sugiono. 2009. Metode Penelitian Bisnis. Bandung: FT. Alfabeta.

Amiruddin; H. Zainal Asikin. 2004. Pengantar Metode Penelitian Hukum. Jakarta: PT. Raja Grafindo Persada.

Darajat. Zakiah. 1997. Ilmu Pendidikan Islam (IPI). Bandung: CV. Pustaka Setia. Hadi. Sutrisno. 1984. Metodologi Research 2. Yogyakarta : UGM.

Moleong, J. Lexy, 2005, Metode Penelitian Kualitatif, Jakarta: PT. Rineka Cipta,

Marimba. Ahmad D. 1962. Pengantar Filsafat Pendidikan Islam. Jakarta: Bulan Bintang.

Surya. Mohammad.2003. Bina Keluarga. Semarang: PT. Aneka Ilmu.

Zuhairini, dkk. Metode Khusus Pendidian Agama. Malang: Biro Ilmiah Fakultas Tarbiyah, IAIN Sunan Ampel. 